\title{
Glutaminyl cyclase contributes to the formation of focal and diffuse pyroglutamate (pGlu)-Aß deposits in hippocampus via distinct cellular mechanisms
}

\author{
Maike Hartlage-Rübsamen • Markus Morawski • Alexander Waniek • Carsten Jäger • \\ Ulrike Zeitschel · Birgit Koch $\cdot$ Holger Cynis $\cdot$ Stephan Schilling $\cdot$ Reinhard Schliebs • \\ Hans-Ulrich Demuth $\cdot$ Steffen Roßner
}

Received: 26 November 2010/Revised: 27 January 2011/Accepted: 27 January 2011/Published online: 8 February 2011

(C) The Author(s) 2011. This article is published with open access at Springerlink.com

\begin{abstract}
In the hippocampal formation of Alzheimer's disease (AD) patients, both focal and diffuse deposits of $\mathrm{A} \beta$ peptides appear in a subregion- and layer-specific manner. Recently, pyroglutamate (pGlu or $\mathrm{pE}$ )-modified $\mathrm{A} \beta$ peptides were identified as a highly pathogenic and seeding $A \beta$ peptide species. Since the $p E$ modification is catalyzed by glutaminyl cyclase (QC) this enzyme emerged as a novel pharmacological target for AD therapy. Here, we reveal the role of $\mathrm{QC}$ in the formation of different types of hippocampal $\mathrm{pE}-\mathrm{A} \beta$ aggregates. First, we demonstrate that both, focal and diffuse $\mathrm{pE}-\mathrm{A} \beta$ deposits are present in defined layers of the AD hippocampus. While the focal type of $\mathrm{pE}-\mathrm{A} \beta$ aggregates was found to be associated with the somata of QC-expressing interneurons, the diffuse type was not. To address this discrepancy, the hippocampus of amyloid precursor protein transgenic mice was analysed. Similar to observations made in $\mathrm{AD}$, focal (i.e. core-
\end{abstract}

M. Hartlage-Rübsamen and M. Morawski contributed equally.

Electronic supplementary material The online version of this article (doi:10.1007/s00401-011-0806-2) contains supplementary material, which is available to authorized users.

M. Hartlage-Rübsamen · M. Morawski · A. Waniek ·

C. Jäger · U. Zeitschel · R. Schliebs · S. Roßner $(\bowtie)$

Paul Flechsig Institute for Brain Research, University of Leipzig,

Jahnallee 59, 04109 Leipzig, Germany

e-mail: steffen.rossner@medizin.uni-leipzig.de

B. Koch · H. Cynis · S. Schilling · H.-U. Demuth ( $\square)$

Probiodrug AG, Biocenter, Weinbergweg 22,

06120 Halle/Saale, Germany

e-mail: hans-ulrich.demuth@ probiodrug.de

H.-U. Demuth

Ingenium Pharmaceuticals $\mathrm{GmbH}$,

Fraunhoferstr. 13, 82152 Martinsried/Munich, Germany containing) $\mathrm{pE}-\mathrm{A} \beta$ deposits originating from QC-positive neurons and diffuse $\mathrm{pE}-\mathrm{A} \beta$ deposits not associated with QC were detected in $\operatorname{Tg} 2576$ mouse hippocampus. The hippocampal layers harbouring diffuse $\mathrm{pE}-\mathrm{A} \beta$ deposits receive multiple afferents from QC-rich neuronal populations of the entorhinal cortex and locus coeruleus. This might point towards a mechanism in which $\mathrm{pE}-\mathrm{A} \beta$ and/or $\mathrm{QC}$ are being released from projection neurons at hippocampal synapses. Indeed, there are a number of reports demonstrating the reduction of diffuse, but not of focal, $A \beta$ deposits in hippocampus after deafferentation experiments. Moreover, we demonstrate in neurons by live cell imaging and by enzymatic activity assays that QC is secreted in a constitutive and regulated manner. Thus, it is concluded that hippocampal $\mathrm{pE}-\mathrm{A} \beta$ plaques may develop through at least two different mechanisms: intracellularly at sites of somatic QC activity as well as extracellularly through seeding at terminal fields of QC expressing projection neurons.

Keywords Alzheimer's disease - Glutaminyl cyclase · Pyroglutamate-A $\beta \cdot$ Seeding $\cdot$ Hippocampus

$\begin{array}{ll}\text { Abbreviations } \\ \text { AD } & \text { Alzheimer's disease } \\ \text { APP } & \text { Amyloid precursor protein } \\ \text { BSA } & \text { Bovine serum albumin } \\ \text { CA } & \text { Cornu ammonis } \\ \text { CERAD } & \begin{array}{l}\text { Consortium to Establish a Registry for } \\ \text { Alzheimer's Disease }\end{array} \\ \text { DAB } & \begin{array}{l}3,3^{\prime} \text {-Diaminobenzidine } \\ \text { DG }\end{array} \\ \text { Dentate gyrus } \\ \text { EGFP } & \text { Enhanced green fluorescent protein } \\ \text { NIA } & \text { National Institute on Aging } \\ \text { PB } & \text { Phosphate buffer }\end{array}$




$\begin{array}{ll}\text { PBS } & \text { Phosphate-buffered saline } \\ \text { pE-A } \beta & \text { Pyroglutamate-modified A } \beta \\ \text { PM } & \text { Postnatal month } \\ \text { QC } & \text { Glutaminyl cyclase } \\ \text { RT } & \text { Room temperature }\end{array}$

\section{Introduction}

Alzheimer's disease (AD) is the most prevalent neurodegenerative disorder characterized by the appearance of neurofibrillary tangles, loss of specific neuronal populations and formation of $A \beta$ deposits in neocortical and hippocampal brain structures and in vulnerable subcortical nuclei (AD) $[7,8,52]$. A $\beta$ peptides are generated by sequential proteolytic cleavage of the amyloid precursor protein (APP) by $\beta$ - and $\gamma$-secretases [23]. A substantial proportion of $A \beta$ peptides undergoes $\mathrm{N}$-terminal truncation by two or by ten amino acids and subsequent cyclization of $\mathrm{N}$-terminal glutamate $(\mathrm{E})$ into pyroglutamate $(\mathrm{pE})$, resulting in $\mathrm{pE} 3-\mathrm{A} \beta$ and $\mathrm{pE} 11-\mathrm{A} \beta$ peptides $[41,44,45]$. Such pE-A $\beta$ peptides have been shown by biochemical and histological methods to be major constituents of $\mathrm{A} \beta$ deposits in sporadic and familial AD [34, 38, 44]. Also in a recent study using mass spectrometry, $\mathrm{pE}-\mathrm{A} \beta$ peptides were identified as a significant-although not predominant-A $\beta$ peptide species in brains from sporadic and familial $\mathrm{AD}$ patients [40]. Based on a number of independent biophysical, biochemical and histological observations, pE-A $\beta$ peptides could play a prominent role in AD pathogenesis. For example, the cyclization of glutamic acid into a $\mathrm{pE}$ residue leads to a loss of $\mathrm{N}$-terminal charge resulting in accelerated aggregation of $\mathrm{pE}-\mathrm{A} \beta[26,42]$ and co-aggregation of non-modified $A \beta$ peptides $[15,31,48,51]$. Furthermore, the $\mathrm{pE}$-modification confers resistance to degradation by most aminopeptidases as well as A $\beta$-degrading endopeptidases [43]. Finally, a particularly neurotoxic effect of $p E-A \beta$ peptides on primary neurons, neuronal cell lines and neurons of APP transgenic animals in vivo has been described $[1,42,59]$.

Recently, glutaminyl cyclase (QC) has been shown to be the enzyme catalyzing pE-A $\beta$ peptide generation in cellfree assays [47], in cell culture [13,14] and in experimental animals $[49,50]$. Chronic inhibition of QC in transgenic mouse and Drosophila models of AD resulted in reduced $\mathrm{pE}-\mathrm{A} \beta$ peptide generation and in diminished total $\mathrm{A} \beta$ peptide concentrations in brain [49]. Thus, the enzymatic activity of $\mathrm{QC}$ appears to be a prerequisite for $\mathrm{pE}-\mathrm{A} \beta$ peptide generation and QC expression may render neurons especially vulnerable.

In mammalian brain, significant neuronal QC expression in the hypothalamus has been described decades ago, and has been shown to be involved in the maturation of peptide hormones such as orexin A, gastrin, gonadotropin- and thyrotropin-releasing hormones and neurotensin $[6,9,20$, 39]. Recently, we demonstrated pronounced QC immunoreactivity in a subpopulation of neocortical neurons and of GABAergic interneurons in the mouse hippocampus [25]. Moreover, we observed robust QC expression in mouse and human brain in $\mathrm{AD}$-vulnerable subcortical brain regions, such as nucleus basalis Meynert, locus coeruleus and Edinger-Westphal nucleus [36].

However, contrary to the thorough biochemical characterization of $\mathrm{pE}-\mathrm{A} \beta$ formation by $\mathrm{QC}$, a conclusive histological relation of $\mathrm{QC}$ expression and $\mathrm{pE}-\mathrm{A} \beta$ pathology in vivo is still lacking. In order to address this issue, we first analysed the $\mathrm{pE}-\mathrm{A} \beta$ immunoreactivity in post mortem hippocampal brain tissue of AD patients. The hippocampus was chosen as model system because of its well-described connectivity and laminated organization with segregated cell and fibre layers [21], early-onset $\mathrm{pE}-\mathrm{A} \beta$ plaque generation and significant QC expression in mouse hippocampus [25]. Here, we report for the first time an analysis of the spatial relation of distinct types of $\mathrm{pE}-\mathrm{A} \beta$ deposits with QC immunoreactive neurons and target fields of QC-rich projection neurons in the human hippocampal formation. To get further insights from an animal model of $\mathrm{AD}$, we also analysed the temporal and spatial occurrence of $\mathrm{pE}-\mathrm{A} \beta$ plaques in APP transgenic Tg2576 mice and related it histologically to QC expression.

\section{Materials and methods}

Human brain tissue

Case recruitment and characterization of human brain tissue

Case recruitment and autopsy were performed in accordance with guidelines effective at Banner Sun Health Research Institute Brain Donation Program of Sun City, Arizona [3]. The required consent was obtained for all cases. The definite diagnosis of $\mathrm{AD}$ for all cases used in this study was based on the presence of neurofibrillary tangles and neuritic plaques in the hippocampal formation and neocortical areas and met the criteria of the National Institute on Aging (NIA) and the Consortium to establish a registry for AD (CERAD) [35]. Hippocampal brain tissue from ten $\mathrm{AD}$ cases and from seven age-matched control subjects was evaluated for $\mathrm{QC}$ expression and for $\mathrm{pE}-\mathrm{A} \beta$ deposition (Table 1). Anatomical subfields and layers of the human hippocampal formation at the level of 13, 23 and $31 \mathrm{~mm}$ were identified using Nissl-stained sections and the atlas of the human brain $[18,30]$. 
Table 1 Human hippocampal brain tissue used for QC and $\mathrm{pE}-\mathrm{A} \beta$ labellings

\begin{tabular}{|c|c|c|c|c|c|c|c|c|c|c|c|}
\hline & $\begin{array}{l}\text { Case } \\
\#\end{array}$ & $\begin{array}{l}\text { PMD } \\
\text { (h) }\end{array}$ & Gender & $\begin{array}{l}\text { Age } \\
\text { (years) }\end{array}$ & $\begin{array}{l}\text { Brain } \\
\text { weight } \\
\text { (g) }\end{array}$ & COD & $\begin{array}{l}\text { Braak } \\
\text { score }\end{array}$ & $\begin{array}{l}\text { MMSE } \\
\text { (last } \\
\text { score) }\end{array}$ & $\begin{array}{l}\text { CERAD } \\
\text { neuritic } \\
\text { plaque score }\end{array}$ & $\begin{array}{l}\text { CERAD } \\
\text { criteria }\end{array}$ & $\begin{array}{l}\text { NIA criteria } \\
\text { (likelihood } \\
\text { of dementia) }\end{array}$ \\
\hline \multirow[t]{7}{*}{ Control } & Co1 & 2.75 & Male & 81 & 1,290 & $\begin{array}{l}\text { Cardiac/respiratory } \\
\text { failure }\end{array}$ & I & - & 0 & Not met & Not met \\
\hline & $\mathrm{Co} 2$ & 2.75 & Female & 85 & 1,020 & Pancreatic cancer & II & - & 0 & Not met & Not met \\
\hline & $\mathrm{Co} 3$ & 1.0 & Female & 85 & 1,085 & Abdominal lymphoma & II & - & 0 & Not met & Not met \\
\hline & $\mathrm{Co} 4$ & 2.5 & Female & 86 & 1,145 & Pulmonary fibrosis & III & $27 / 30$ & 0 & Not met & Not met \\
\hline & Co5 & 3.0 & Female & 89 & 1,200 & $\begin{array}{l}\text { Congestive heart } \\
\text { failure }\end{array}$ & III & $30 / 30$ & A & Not met & Not met \\
\hline & Co6 & 2.75 & Female & 75 & 1,110 & Pulmonary embolus & III & $29 / 30$ & 0 & Not met & Not met \\
\hline & $\mathrm{Co} 7$ & 3.0 & Male & 82 & 1,240 & Renal failure/COPD & III & $26 / 30$ & A & Not met & Not met \\
\hline Mean & & 2.5 & $5 / 2$ & 83.3 & 1,155 & & & & & & \\
\hline \multirow[t]{10}{*}{$\mathrm{AD}$} & AD1 & 4.0 & Female & 82 & 932 & Failure to thrive; AD & VI & - & $\mathrm{C}$ & Definite AD & High \\
\hline & AD2 & 3.0 & Female & 82 & 925 & $\begin{array}{l}\text { Cardiac/respiratory } \\
\text { failure }\end{array}$ & VI & - & $\mathrm{C}$ & Definite AD & High \\
\hline & AD3 & 1.5 & Female & 85 & 850 & Failure to thrive & VI & - & $\mathrm{C}$ & Definite AD & High \\
\hline & $\mathrm{AD} 4$ & 1.5 & Female & 79 & 950 & $\begin{array}{l}\text { Cardiac/respiratory } \\
\text { failure; } \mathrm{AD}\end{array}$ & VI & - & $\mathrm{C}$ & Definite AD & High \\
\hline & AD5 & 1.83 & Female & 84 & 1,080 & End stage AD & VI & $00 / 30$ & $\mathrm{C}$ & Definite AD & High \\
\hline & AD6 & 1.5 & Female & 85 & 940 & $\begin{array}{l}\text { Breast cancer; } \\
\text { end stage } \mathrm{AD}\end{array}$ & VI & $02 / 30$ & $\mathrm{C}$ & Definite AD & High \\
\hline & AD7 & 2.25 & Male & 78 & 1,120 & $\mathrm{AD}$ & VI & $07 / 30$ & $\mathrm{C}$ & Definite AD & High \\
\hline & AD8 & 3.16 & Male & 80 & 1,000 & $\mathrm{AD}$ & VI & $01 / 30$ & $\mathrm{C}$ & Definite AD & High \\
\hline & AD9 & 3.5 & Male & 77 & 1,200 & End stage AD & VI & $04 / 30$ & $\mathrm{C}$ & Definite AD & High \\
\hline & AD10 & 2.5 & Male & 87 & 1,100 & End stage $\mathrm{AD}$ & VI & $13 / 30$ & $\mathrm{C}$ & Definite AD & High \\
\hline Mean & & 2.5 & $6 / 4$ & 81.9 & 1,010 & & & & & & \\
\hline
\end{tabular}

AD Alzheimer's disease, $P M D$ post mortem delay, Co control, $C O D$ cause of death, MMSE Mini-Mental State Examination, CERAD Consortium to Establish a Registry for Alzheimer's Disease ( $O$ none, $A$ sparse, $B$ moderate, $C$ frequent), NIA National Institute on Aging

\section{Tissue preparation}

Fifteen-millimeter-thick tissue blocks were prepared in the frontal plane according to the atlas of the human brain [30] and fixed in $4 \%$ paraformaldehyde in $0.1 \mathrm{M}$ phosphatebuffered saline (PBS), pH 7.4 for 3-4 days. Areas containing the regions of interest were cryoprotected in $30 \%$ sucrose in $0.1 \mathrm{M}$ PBS, $\mathrm{pH}$ 7.4. Series of $30-\mu \mathrm{m}$-thick sections were cut on a freezing microtome and collected in PBS containing $0.1 \%$ sodium azide.

\section{Experimental animals}

In order to relate $\mathrm{QC}$ expression to $\mathrm{pE}-\mathrm{A} \beta$ formation, female wild-type and APP transgenic Tg2576 mice at the postnatal age of 10, 12, 14, 16, 18 and 23 months were used for this study ( $N=3-5$ per age group). As control for the specificity of the QC immunohistochemical labelling, QC knock-out mice generated on the basis of classical homologous recombination approach were included [25, 36]. Cre-mediated excision of exons 5 and 6 was confirmed by PCR and
RT-PCR. The constitutive deletion of these exons resulted in an additional frame shift and thus in a complete loss of the C-terminal part of the protein (not shown).

Preparation of mouse brains for immunohistochemistry

Mice were deeply anaesthetized with pentobarbital and perfused transcardially with $50 \mathrm{ml} 0.9 \%$ saline containing $0.1 \%$ heparin followed by perfusion with $80 \mathrm{ml} 4 \%$ paraformaldehyde in PBS (0.1 M; pH 7.4). The brains were removed from the skull and postfixed by immersion in the same fixative overnight at $4^{\circ} \mathrm{C}$. After cryoprotection in $30 \%$ sucrose in $0.1 \mathrm{M}$ PBS for 3 days, the brains were snap-frozen in $n$-hexane at $-68^{\circ} \mathrm{C}$ and stored at $-20^{\circ} \mathrm{C}$. Coronal sections $(30 \mu \mathrm{m})$ were cut on a sliding microtome and collected in $0.1 \mathrm{M}$ PBS.

$\mathrm{QC}$ and $\mathrm{pE}-\mathrm{A} \beta$ antibodies

Immunohistochemistry to detect QC in human brain was performed using a commercially available mouse anti- 
human QC antiserum (A01; Abnova; 1:500). Additionally, the specificity of QC immunolabelling was validated by similar staining patterns obtained employing the rabbit anti-QC antiserum 1301 (1:500), which was raised against recombinant full-length mouse QC expressed in yeast. This antiserum has been characterized recently $[25,36]$ and was shown to detect mouse, rat and human QC in Western blot analysis and immunohistochemistry, which appears conceivable considering a $85 \%$ protein sequence identity. Moreover, the specificity of the QC antiserum was previously shown by the robust labelling of mouse hypothalamic neurons, a known source of QC and of peptide hormones modified by QC, and by the absence of this labelling in brains from QC knock-out mice [25, 36].

$\mathrm{pE}-\mathrm{A} \beta$ peptides in brains of transgenic mice and of $\mathrm{AD}$ patients were detected using the mouse monoclonal antibody mab2-48 (Synaptic Systems, Göttingen, Germany), which has been thoroughly characterized by Wirths et al. [60]. This antibody specifically detects the $\mathrm{pE} 3-\mathrm{A} \beta$ neoepitope generated by QC activity and does not cross-react with endogenous mouse $A \beta$ nor with human $A \beta 1-40 / 42$, $\mathrm{N}$-truncated human $\mathrm{A} \beta 3-40 / 42$ lacking the $\mathrm{pE}$ modification, or $\mathrm{pE} 11-\mathrm{A} \beta$. When required for double-labelling procedures a rabbit anti-pE-A $\beta$ antiserum (Synaptic Systems) was used. The rabbit anti-pE-A $\beta$ and mouse anti-pE$\mathrm{A} \beta$ antibodies showed an identical staining pattern in mouse and human brain tissue as revealed by double immunofluorescent labelling (not shown).

\section{Immunohistochemical labellings}

A detailed description of the single, double and triple immunohistochemical labellings performed in human and in Tg2576 mouse brain sections is given in the Supplementary Information 1. Briefly, specific primary antibodies raised in different species and standard immunochemical protocols were followed to reveal co-localization of $\mathrm{pE}-\mathrm{A} \beta$ with $\mathrm{QC}$ and with total $\mathrm{A} \beta$ peptide pools. The presence of the respective antigens was visualized using chromogens (DAB, DAB-Ni) and fluorescent dyes (Cy2, Cy3, TOPRO$3)$ as described in $[25,36]$.

\section{Confocal laser scanning microscopy}

Laser scanning microscopy (LSM 510, Zeiss, Oberkochen, Germany) was performed to reveal co-localization of (1) $\mathrm{QC}$ with $\mathrm{pE}-\mathrm{A} \beta$ and cellular nuclei or (2) $\mathrm{pE}-\mathrm{A} \beta$ with total $\mathrm{A} \beta$ pools. For Cy2-labelled antigens (green fluorescence), an argon laser with $488 \mathrm{~nm}$ excitation was used and emission from Cy2 was recorded at $510 \mathrm{~nm}$ applying a low-range band pass $(505-550 \mathrm{~nm})$. For Cy3-labelled antigens (red fluorescence), a helium-neon laser with $543 \mathrm{~nm}$ excitation was used and emission from $\mathrm{Cy} 3$ at
$570 \mathrm{~nm}$ was detected applying high-range band pass (560-615 nm). Nuclei labelled with TOPRO-3 were visualized by excitation at $633 \mathrm{~nm}$ and detection of TOPRO-3 emission above a long pass of $655 \mathrm{~nm}$.

\section{Receptor autoradiography}

Receptor autoradiography to detect adrenergic receptor subtypes as a measure of noradrenergic hippocampal innervation in rodent brain was carried out as described previously [27]. Briefly, $12-\mu \mathrm{m}$-thick brain slices cut in the coronal plane were mounted onto gelatin-coated slides and pre-incubated with $170 \mathrm{mM}$ Tris- $\mathrm{HCl}(\mathrm{pH}$ 7.4) at $\mathrm{RT}$ for 15 min to wash out endogenous ligand and to equilibrate the brain tissue. For the detection of the $\alpha 1$-adrenoceptor, brain sections were incubated in the same buffer containing $1 \mathrm{nM}\left[{ }^{3} \mathrm{H}\right]$ prazosine for $30 \mathrm{~min}$ at RT. The $\alpha 2$-adrenoceptor subtype was detected using $\left[{ }^{3} \mathrm{H}\right]$ rauwolscine $(5 \mathrm{nM})$ as radioligand. As $\left[{ }^{3} \mathrm{H}\right]$ rauwolscine does not discriminate between $\alpha 2$-adrenoceptors and $5-\mathrm{HT}_{1 \mathrm{~A}}$ receptors, $5-\mathrm{HT}_{1 \mathrm{~A}}$ receptors were masked with unlabelled serotonin $(0.3 \mu \mathrm{M})$ and the incubation was performed for $30 \mathrm{~min}$ at RT. The presence of the $\beta 1 / 2$-adrenoceptor was determined using $\left[{ }^{3} \mathrm{H}\right]$ dihydroalprenolol $(3 \mathrm{nM})$ as radioligand for $1 \mathrm{~h}$ at RT. After the respective incubation periods, sections were washed twice in ice-cold buffer for $5 \mathrm{~min}$, followed by a short dipping into ice-cold distilled water. The labelled and dried tissue sections were then apposed to tritium-sensitive film $\left({ }^{3} \mathrm{H}\right.$-Hyperfilm, Amersham) at $4{ }^{\circ} \mathrm{C}$ for $3-5$ weeks. The films were developed with Kodak D19 developer for $5 \mathrm{~min}$, fixed, rinsed and dried. Optical density readings from the autoradiographs obtained were recorded across the hippocampus using the MCID image analysis program (Imaging Research Inc., St. Catharines, Ontario, Canada), corrected for background and displayed as thick profiles from dorsal to ventral.

\section{Cell culture and QC enzymatic activity assays}

Next, we employed cell culture experiments to elucidate whether QC protein accumulates intracellularly or whether it is constitutively released into the culture medium by QC expressing neurons. For this purpose, different neuronal cell types were used, i.e. the QC expressing mouse hypothalamic neuronal cell line GT1-7 [32], kindly provided by I. Vorberg/H. Schätzl; Institute of Virology at Technical University of Munich, and mouse primary neurons derived from wild type and from QC knock-out foetuses of gestation day 16. Three days after seeding neurons in DMEM containing $5 \%$ horse serum and $1 \times$ antibiotic mixture, the medium was replaced by serum-free cultivation medium and cultures were maintained for 1,3 and 5 days in vitro without change of medium. At the end of the cultivation 
period, the conditioned medium was collected; the cells were harvested, washed in PBS, centrifuged at $800 \times g$ for 8 min and stored at $-20^{\circ} \mathrm{C}$ pending QC activity measurements. In another set of experiments, veratridine (Sigma; $50 \mu \mathrm{M}$ ) and potassium chloride (Sigma; $50 \mathrm{mM}$ ) were used to pharmacologically stimulate vesicular release by neuronal depolarization in 15 min pulse experiments.

QC activity was measured by a discontinuous HPLCmethod using the substrate H-Gln- $\beta \mathrm{NA}$ as described previously [13]. Briefly, QC containing cell lysate or cell culture supernatant was incubated with substrate H-Gln$\beta N A$. Test samples were taken and reaction was stopped by boiling for $5 \mathrm{~min}$. Analysis for pGlu- $\beta$ NA formation was done using RP18 LiChroCART HPLC Cartridge and the HPLC-system D-7000 (Merck-Hitachi). QC activity was quantified from a standard curve of pGlu- $\beta$ NA under assay conditions.

\section{QC live cell imaging}

In order to demonstrate transport of QC in neuronal processes, live cell imaging was performed. Constructs encoding QC fused to enhanced green fluorescent protein (QC-EGFP) were generated as described elsewhere [14]. The construct was confirmed by sequencing and isolated for cell culture purposes using EndoFree Plasmid Maxi Kit (Qiagen). Transfection of GT1-7 cells differentiated by serum deprivation for $72 \mathrm{~h}$ was performed by incubation with $10 \mu \mathrm{l}$ lipofectamine 2000 (Invitrogen) and $4 \mu \mathrm{g}$ plasmid DNA per well for $6 \mathrm{~h}$. Twelve hours after transfection, QC-EGFP was detected using a Zeiss Cell Observer system equipped with an Axiocam MRC and a $63 \times$ objective lens. In control experiments, cells were transfected with EGFP constructs lacking the QC cDNA.

\section{Statistical analyses}

Quantitative data on QC enzymatic activity given in Fig. 6 are mean values of five independent experiments \pm SEM. Data were analysed by one-way ANOVA, followed by post hoc analysis (Newman-Keuls test).

\section{Results}

$\mathrm{A} \beta$ deposit/plaque nomenclature

In this paper, we employ the terms "focal" and "diffuse" $\mathrm{A} \beta$ deposits to distinguish between dense plaque morphology containing a neuronal soma or remains thereof on the one hand and more loosely aggregated $\mathrm{pE}-\mathrm{A} \beta$ without apparent association with a neuronal cell body on the other. In analogy to current classifications of $A \beta$ plaque pathology (reviewed in [17]) the term focal deposit relates to dense-cored [16], neuritic [8], and classic and compact [2] plaques. Since we focused on the relationship between $\mathrm{QC}$ expression and $\mathrm{pE}-\mathrm{A} \beta$ aggregation, the presence or absence of dystrophic neurites was not included in the plaque classification.

\section{$\mathrm{pE}-\mathrm{A} \beta$ deposition in $\mathrm{AD}$ hippocampus}

In the human hippocampal formation from $\mathrm{AD}$ subjects, $\mathrm{pE}-\mathrm{A} \beta$ deposits were detected in a structured, laminated orientation as shown in Fig. 1a. In particular, pE-A $\beta$ deposits were found lined-up in the dentate gyrus (DG) molecular layer. Additionally, $\mathrm{pE}-\mathrm{A} \beta$ aggregates were detected in stratum lacunosum moleculare and stratum radiatum of the hippocampus proper but barely in granular and pyramidal cell layers. The pattern of $\mathrm{pE}-\mathrm{A} \beta$ deposits described above was found at different levels of the $\mathrm{AD}$ hippocampal formation (Fig. 1b). In contrast, hippocampal brain sections from control subjects were almost devoid of pE-A $\beta$ deposits (Fig. 1b) and of plaques composed of unmodified $A \beta$ peptides (not shown). Interestingly, $p E-A \beta$ deposits present in the AD hippocampus differed significantly with respect to their morphology and to their association with QC. Applying two different histological double-labelling procedures depending on (1) peroxidase as marker enzyme and (2) immunofluorescent labellings, a diffuse type of $\mathrm{pE}-\mathrm{A} \beta$ aggregates not associated with $\mathrm{QC}$ immunoreactive neurons and a dense-core type of $\mathrm{pE}-\mathrm{A} \beta$ deposits frequently associated with $\mathrm{QC}$ positive neurons were identified (Fig. 1c).

Developmental profile of $\mathrm{pE}-\mathrm{A} \beta$ aggregate formation in $\mathrm{Tg} 2576$ mouse brain

To substantiate observations made in $\mathrm{AD}$ brain in an animal model of $\mathrm{AD}$, the temporal and spatial appearance of $\mathrm{pE}-\mathrm{A} \beta$ was studied in brains of APP transgenic Tg2576 mice at the age of postnatal month (PM) 10, 12, 14, 16, 18 and 23. pE-A $\beta$ immunoreactive deposits were already detectable at PM 10 in entorhinal cortex. At later stages, $\mathrm{pE}-\mathrm{A} \beta$ deposits also appeared in cingulate cortex (PM 12), in the DG molecular layer (PM 14), in stratum lacunosum moleculare and striatum (PM 16), in parietal cortex (PM 18) and more hippocampal and neocortical subfields (PM 23) (Fig. 2). During the aging process, $p E-A \beta$ load in all affected brain structures steadily increased.

Relation of QC expression to $\mathrm{pE}-\mathrm{A} \beta$ deposition in $\mathrm{Tg} 2576$ hippocampus

In order to relate $\mathrm{QC}$ expression to $\mathrm{pE}-\mathrm{A} \beta$ generation by individual neurons and to $\mathrm{pE}-\mathrm{A} \beta$ plaque formation, we 
a $\quad \mathrm{pE}-\mathrm{A} \beta$ in human hippocampus
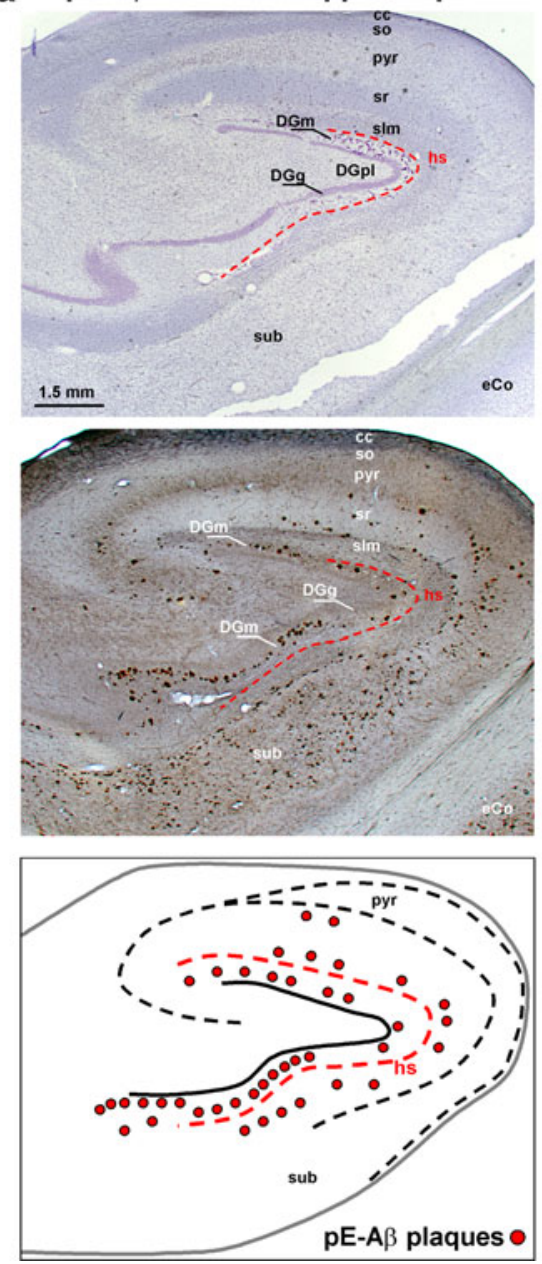

Fig. 1 pE-A $\beta$ deposition in human hippocampus. a In the human hippocampal formation, $\mathrm{pE}-\mathrm{A} \beta$ deposits were detected in a structured, laminated orientation as shown here at the transverse level of $23 \mathrm{~mm}$. The Nissl staining (top) visualizes the hippocampal lamination and allows to spatialize $\mathrm{pE}-\mathrm{A} \beta$ deposits detected in consecutive brain sections (middle). In particular, $\mathrm{pE}-\mathrm{A} \beta$ deposits were found lined-up in the DG molecular layer. Additionally, $\mathrm{pE}-\mathrm{A} \beta$ aggregates were detected in stratum lacunosum moleculare $(s / m)$ and stratum radiatum $(s r)$ of the hippocampus proper but barely in granular and pyramidal cell layers. This localization is shown schematically in the bottom image (bottom). The scale bar in the top microphotograph applies to all images. $\mathbf{b}$ The pattern of $\mathrm{pE}-\mathrm{A} \beta$ deposits described in a can be also found at other levels of the AD hippocampal formation as shown in 3 columns from left to right. In contrast, hippocampal brain sections

analysed the hippocampus of APP transgenic Tg2576 mice. As demonstrated in Fig. 3, most QC expressing interneurons in the hippocampal formation were detected along the stratum lacunosum moleculare of the hippocampus proper. QC immunoreactive neurons were also present in the polymorphic and at lower density in the molecular layer of DG, as well as in strata radiatum and oriens of cornu ammonis, but were largely absent from granular and pyramidal cell layers (Fig. 3). These principal cell layers did not show significant numbers of $\mathrm{pE}-\mathrm{A} \beta$ deposits.

\section{wo types of $\mathrm{pE}-\mathrm{A} \beta$ deposits in human hippocampus}
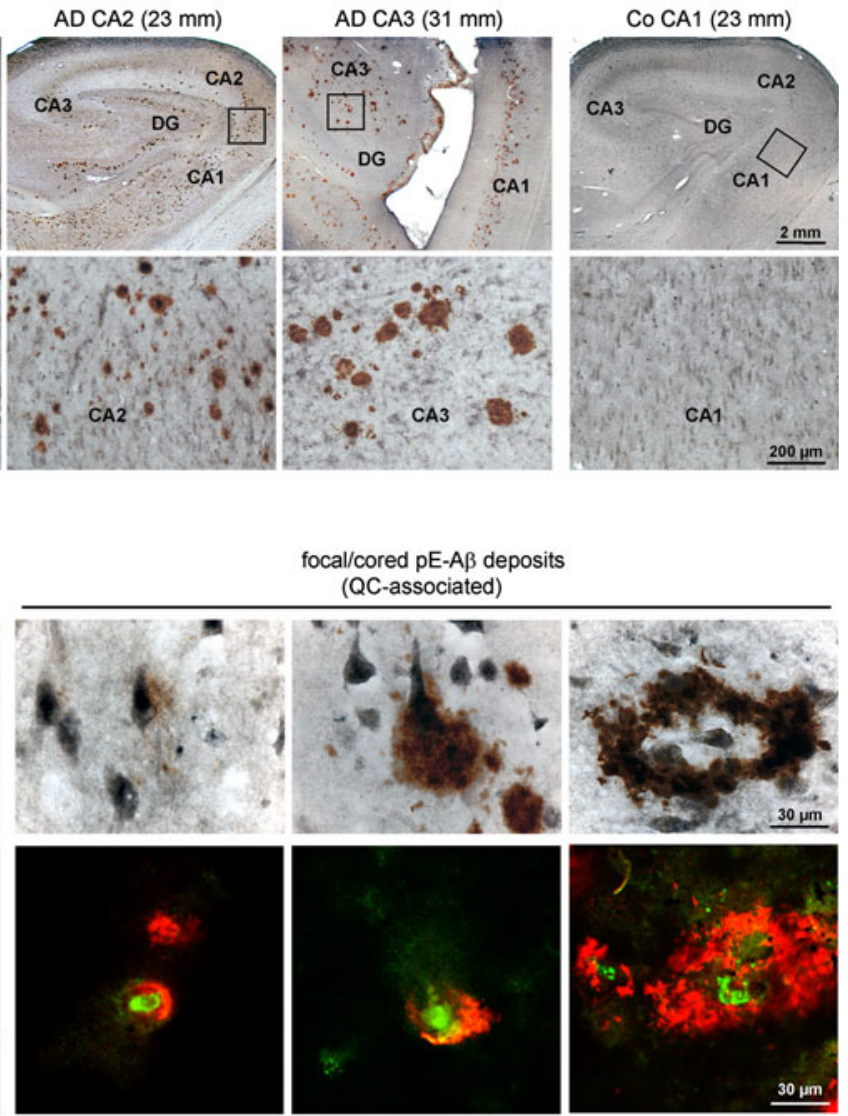

from control subjects $(\mathrm{Co})$ appear devoid of pE-A $\beta$ deposits (right). c Typical examples of $\mathrm{pE}-\mathrm{A} \beta$ plaque morphology and its relation to QC. Both, DAB/DAB-Ni (top) and fluorescent labellings (bottom) reveal a diffuse type of $\mathrm{pE}-\mathrm{A} \beta$ aggregates not associated with $\mathrm{QC}$ immunoreactive neurons and a focal, more condensed type of $\mathrm{pE}-\mathrm{A} \beta$ deposits frequently associated with QC-positive neuronal somata. The scale bars in $\mathbf{b}$ and $\mathbf{c}$ apply to all images in one line. $c c$ corpus callosum, so stratum oriens, $p y r$ pyramidal cell layer, $s r$ stratum radiatum, $\operatorname{sim}$ stratum lacunosum moleculare, $D G$ dentate gyrus, $D G m$ molecular layer of dentate gyrus, $D G p l$ polymorphic layer (hilus) of dentate gyrus, $D G g$ granular layer of dentate gyrus, $h s$ vestigial hippocampal sulcus, $e C o$ entorhinal cortex, $C A$ cornu ammonis, $\operatorname{PrS}$ presubiculum, $S u b$ subiculum

$\mathrm{pE}-\mathrm{A} \beta$ plaques were most abundantly formed in the DG molecular layer just below the hippocampal fissure, but to a lesser extent in strata lacunosum moleculare and oriens (Fig. 3). Thus, there is only a weak spatial correlation between highest numbers of QC immunoreactive neurons on the one hand and highest density of $\mathrm{pE}-\mathrm{A} \beta$ deposits on the other in specific layers of the aged $\operatorname{Tg} 2576$ hippocampus.

Attempting to unveil the cause for this discrepancy, we performed double immunofluorescent labellings for QC and $\mathrm{pE}-\mathrm{A} \beta$ and analysed the morphology of hippocampal 
Fig. 2 Developmental profile of $\mathrm{pE}-\mathrm{A} \beta$ formation in $\operatorname{Tg} 2576$ mouse brain. $\mathrm{pE}-\mathrm{A} \beta$ immunoreactive deposits were detected from PM 10 onwards. At this age, $\mathrm{pE}-\mathrm{A} \beta$ deposits were only present in the entorhinal cortex. The brain structure affected at the next postnatal age analysed was cingulate cortex (PM 12), followed by DG molecular layer (PM 14), stratum lacunosum moleculare and striatum (PM 16), parietal cortex (PM 18) and more hippocampal and neocortical subfields (PM 23). In each brain region affected by $\mathrm{pE}-\mathrm{A} \beta$ pathology, there was an increase in the $\mathrm{pE}-\mathrm{A} \beta$ load at older ages
Developmental and spatial appearance of $\mathrm{pE}-\mathrm{A} \beta$ deposits
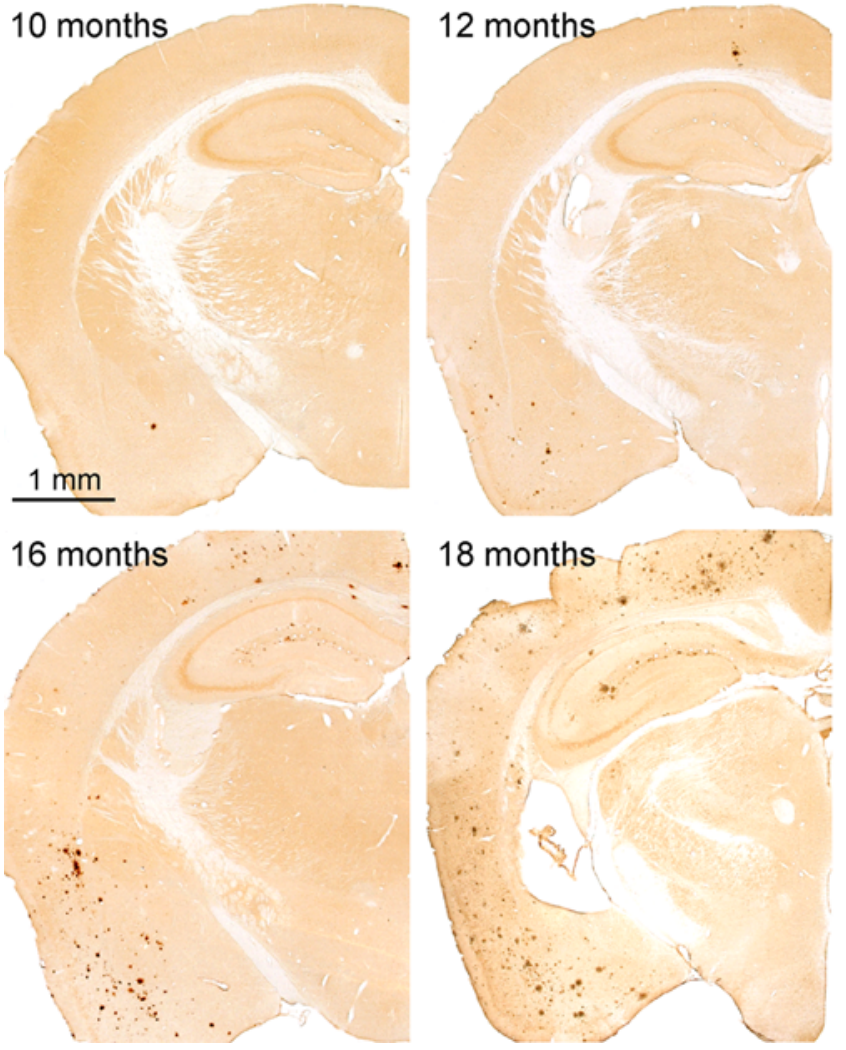
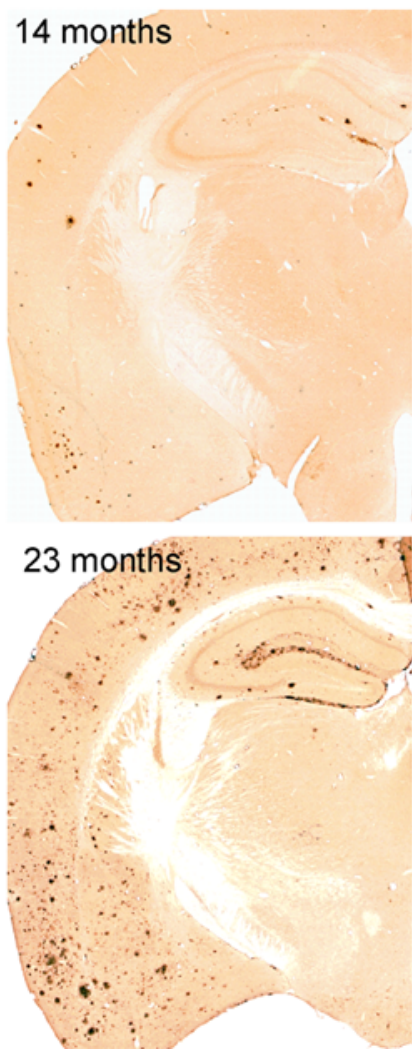

pE-A $\beta$ deposits with respect to local QC expression. Along the hippocampal stratum lacunosum moleculare, a layer with numerous QC immunoreactive interneurons, we frequently observed intraneuronal $\mathrm{pE}-\mathrm{A} \beta$ accumulation as well as $\mathrm{pE}-\mathrm{A} \beta$ aggregates displaying the size and shape of neurons (Fig. 4a). In many cases, QC immunoreactivity and nuclear staining were also detected in these aggregates suggesting that this type of $\mathrm{pE}-\mathrm{A} \beta$ aggregate may have directly emanated from the somata of QC expressing interneurons.

In contrast, the DG molecular layer contained relatively few QC expressing interneurons, compared to an increasingly high $\mathrm{pE}-\mathrm{A} \beta$ plaque load in aging transgenic animals. Interestingly, $\mathrm{pE}-\mathrm{A} \beta$ deposits in the $\mathrm{DG}$ molecular layer frequently exhibited a different morphology compared to the dense type described above. These plaques appeared more diffuse, lacked the neuron-like shape and displayed neither QC immunoreactivity nor neuronal nuclei staining in their center (Fig. 4b). We thus considered the possibility of an alternative mechanism of QC-driven $\mathrm{pE}-\mathrm{A} \beta$ plaque generation in the hippocampus in addition to $\mathrm{pE}-\mathrm{A} \beta$ accumulation in the cell bodies of local QC synthesizing interneurons. There are a number of reports demonstrating that general $\mathrm{A} \beta$ plaque deposition in the DG molecular layer of APP transgenic mice is dependent on the intact perforant and alvear pathways arising from the entorhinal cortex $[10,28]$. This is consistent with axonal transport of $A \beta$ and its synaptic release [37]. In analogy, we considered a mechanism in which $\mathrm{QC}$ and/or $\mathrm{pE}-\mathrm{A} \beta$ could be released by afferents of projection neurons terminating in defined hippocampal subfields such as the DG molecular layer. The entorhinal cortex on its part expresses significant amounts of $\mathrm{QC}$ and is the first brain region affected by $\mathrm{pE}-\mathrm{A} \beta$ pathology in Tg2576 mice (see Fig. 2).

\section{Composition of $\mathrm{pE}-\mathrm{A} \beta$ versus unmodified $\mathrm{A} \beta$ in plaques}

Based on the unique aggregation velocity of $\mathrm{pE}-\mathrm{A} \beta$ peptides compared to any other form of $A \beta$ peptides, a function of $\mathrm{pE}$-modified $\mathrm{A} \beta$ peptides as seed for aggregation and co-aggregation of unmodified $A \beta$ has been postulated. If this hypothesis was true, $\mathrm{pE}-\mathrm{A} \beta$ should be localized in the center of such aggregates, coated by unmodified $A \beta$. To address this issue, double immunofluorescent labellings of $\mathrm{A} \beta$ with $\mathrm{pE}-\mathrm{A} \beta$-specific and general $\mathrm{A} \beta$ antibodies (4G8) were performed. As shown for the Tg2576 hippocampus in Fig. 5, pE-A $\beta$ was always detected in the center of morphologically different types of $A \beta$ aggregates and covered by non-pE-A $\beta$ peptides. Similar observations were made for human brain tissue (not shown). It is important to note that antibody $4 \mathrm{G} 8$, when 
Fig. 3 Spatial relation of QC and $\mathrm{pE}-\mathrm{A} \beta$. Immunohistochemistry for QC (top) revealed a low number of QC-positive neurons in the DG molecular layer $(D G m)$ below the hippocampal fissure ( $h f$, dotted red line), in stratum oriens (so) and in the polymorphic layer of DG $(D G p l)$. The highest number of $\mathrm{QC}$ immunoreactive neurons was detected in the stratum lacunosum moleculare (slm) of the hippocampus proper, above the hippocampal fissure. Along this hippocampal layer and in stratum oriens (so) early pE-pathology was already observed in 16-month-old $\mathrm{Tg} 2576$ mice, matching the presence of QC neurons (middle). However, the highest density of $\mathrm{pE}$ $\mathrm{A} \beta$ deposits was detected in the molecular layer of the DG (below the hippocampal fissure), which only contained few QC immunoreactive neurons. Bottom a schematic representation of the localization and density of QC immunoreactive neurons (green triangles) and $\mathrm{pE}-\mathrm{A} \beta$ deposits (red circles) in mouse hippocampus is shown. $c c$ corpus callosum, so stratum oriens, $p y r$ pyramidal cell layer, $s r$ stratum radiatum, $s \mathrm{~m}$ stratum lacunosum moleculare, $D G m$ molecular layer of dentate gyrus, $D G p l$ polymorphic layer (hilus) of dentate gyrus, $D G g$ granular layer of dentate gyrus, $h f$ hippocampal fissure

applied at low dilution, also recognizes full-length APP and longer APP fragments harbouring the 4G8 epitope. However, at the high dilution used here $(1: 5,000)$, the antibody then detects only $\mathrm{A} \beta$ [11].

A role of noradrenergic hippocampal innervation for diffuse $\mathrm{pE}-\mathrm{A} \beta$ plaque formation?

In order to obtain evidence for a contribution of QC expressed by distant projection neurons in the formation of diffuse hippocampal $\mathrm{pE}-\mathrm{A} \beta$ plaques, three alternative approaches were employed. Firstly, we visualized noradrenergic receptors in the hippocampal formation by receptor autoradiography as a measure of noradrenergic innervation. Autoradiographs revealed significant and lamina-specific expression of $\alpha 1, \alpha 2$ and $\beta 1 / 2$ noradrenergic receptor subtypes in particular in the DG molecular layer and the stratum lacunosum moleculare (Fig. 6a), indicating a substantial noradrenergic innervation of the layers harbouring diffuse $\mathrm{pE}-\mathrm{A} \beta$ deposits. In contrast, pyramidal and granular cell layers, which do not exhibit diffuse $\mathrm{pE}-\mathrm{A} \beta$ aggregates, displayed — if any-only a low density of these noradrenergic receptor subtypes. Secondly, we quantified intracellular versus secreted QC in mouse hypothalamic GT1-7 neurons and in primary neurons over defined cultivation periods. After $24 \mathrm{~h}$ of cultivation, QC activity in conditioned media was 10-times higher than intracellular QC activity (Fig. 6b). Moreover, we observed stable intracellular QC activity but a 2.5 -fold increase in QC activity in the cultivation medium over a period of 5 days (Fig. 6b), consistent with QC being constitutively secreted from neuronal cells. Additionally, the secretion of enzymatically active QC was reduced in a gene dosagedependent manner in primary neuronal cultures from QC knock-out mice (Fig. 6b). Finally, neuronal depolarization by application of a high extracellular $\mathrm{K}^{+}$concentration
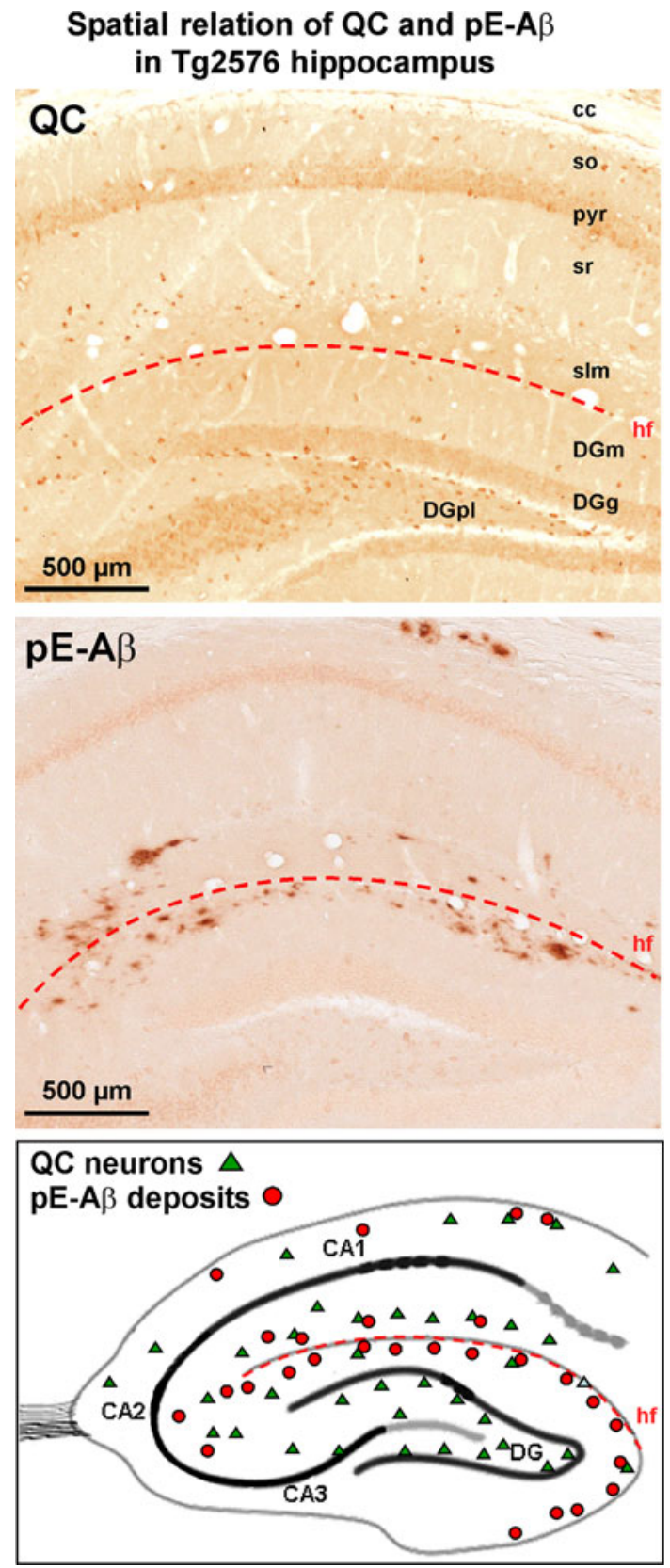

$(50 \mathrm{mM})$ or by veratridine treatment $(50 \mu \mathrm{M})$ in $15 \mathrm{~min}$ pulse experiments resulted in a modest stimulation of QC secretion by 24 and $53 \%$, respectively.

Thirdly, live cell imaging of QC-EGFP-transfected GT1-7 cells demonstrated fast transport of QC in neuronal processes (Fig. 6c). Together, these data demonstrate that QC is transported in neurites and is for the most part constitutively secreted from neuronal cells. In addition, QC was released in a regulated manner, after stimulation with $\mathrm{KCl}$ or veratridine. Therefore, it appears reasonable to conclude that the enzyme exerts its enzymatic activity in vivo in target areas distant from the somata of QCexpressing neurons. 
Fig. 4 Lamina-specific appearance of focal and diffuse $\mathrm{pE}-\mathrm{A} \beta$ deposits. a $\mathrm{QC}$ and $\mathrm{pE}-$ $\mathrm{A} \beta$ co-occur at sites of $\mathrm{QC}$ immunoreactive interneurons. In the stratum lacunosum moleculare of the hippocampus, $\mathrm{pE}-\mathrm{A} \beta$ aggregates often appeared in neuron-like structures. In the DAB labelling (top) $\mathrm{pE}-\mathrm{A} \beta$ was often present intraneuronally or forming a neuron-like rim. Double immunofluorescent labellings frequently revealed cooccurrence of $\mathrm{pE}-\mathrm{A} \beta$ (red) with its anabolic enzyme QC (green). The bottom left figure shows an example of a QC-expressing neuron with intraneuronal $\mathrm{pE}$ $\mathrm{A} \beta$ labelling. The cellular origin of $\mathrm{QC}$ and $\mathrm{pE}-\mathrm{A} \beta$ is demonstrated by the colabelling of the nucleus (blue). In the bottom right figure an example of a disrupted QClabelled neuron is shown. In that case, $\mathrm{pE}-\mathrm{A} \beta$ appeared as a neuronal rim-like structure and contained defragmented nuclear material. b Hippocampal pE-A $\beta$ deposits in a Tg2576

hippocampal layer with few QC neurons. In the DG molecular layer of the hippocampal formation-which only contains few QC immunoreactive neurons-there was a significant number of diffuse $\mathrm{pE}-\mathrm{A} \beta$ plaques (top), which differed morphologically from those arising from QC immunoreactive interneurons of the stratum lacunosum moleculare. These diffuse plaques were not associated with QC immunoreactive somata (bottom left and bottom right) and were detected in target fields that receive input from projection neurons of the ipsilateral entorhinal cortex and locus coeruleus

\section{a} Cored $\mathrm{pE}-\mathrm{A} \beta$ deposits at sites of $\mathrm{QC}$-ir interneurons
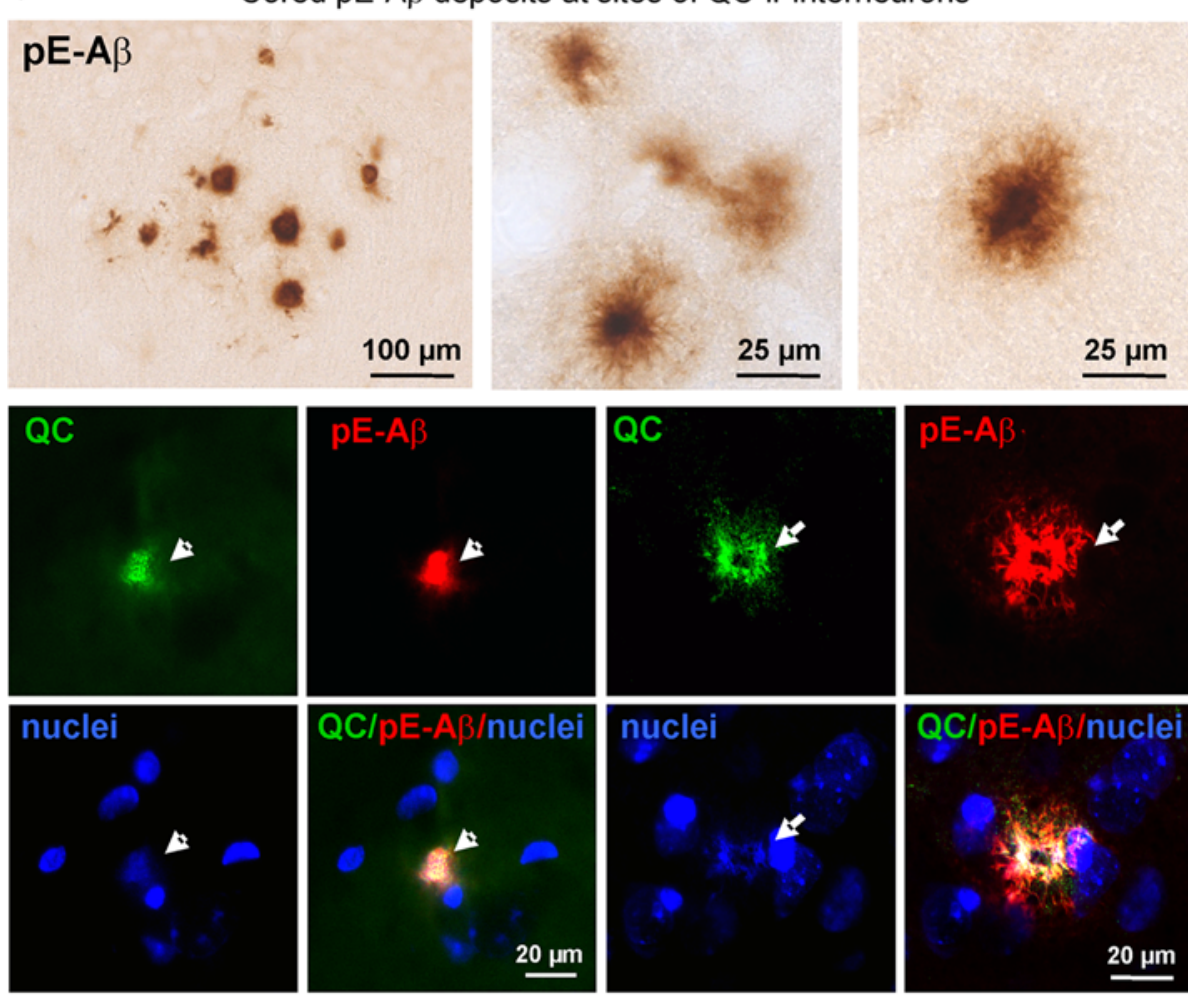

b Diffuse $p E-A \beta$ deposits at terminal sites of projection neurons
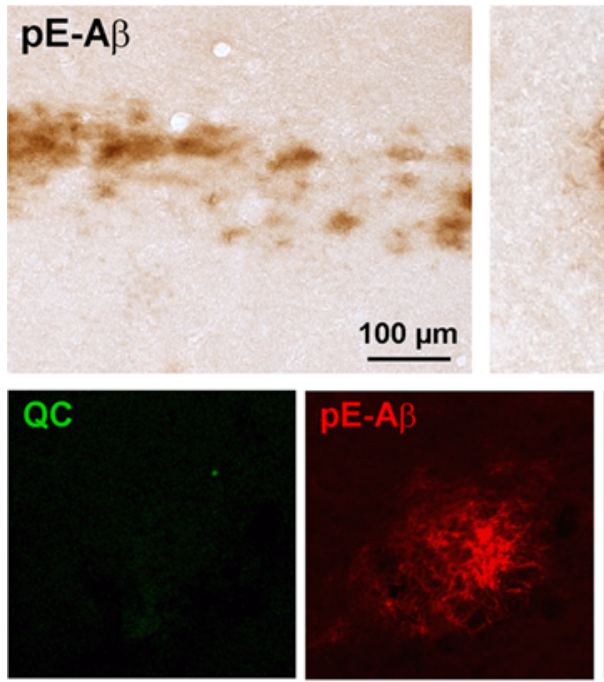

$25 \mu \mathrm{m}$

$25 \mu \mathrm{m}$
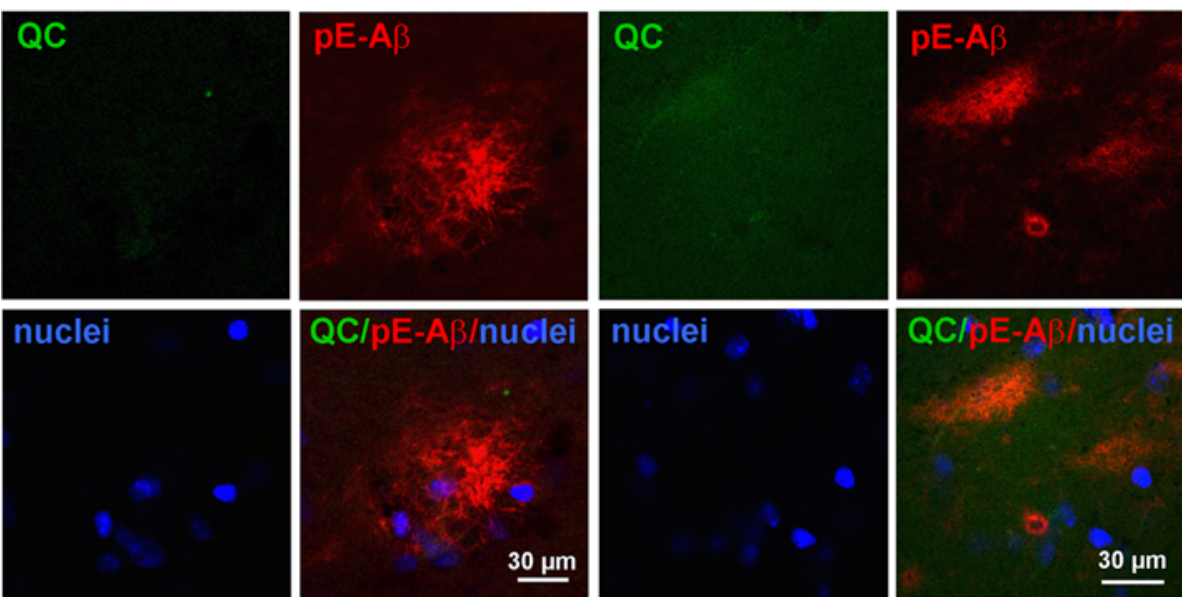

\section{Discussion}

The aim of this study was to reveal the spatial relation of $\mathrm{QC}$-expressing neurons with $\mathrm{pE}-\mathrm{A} \beta$ aggregates in brain.
For a number of reasons, the hippocampus was used as a model system to address that question: (1) it is structured in defined layers that are (2) characterized by the presence of high versus low numbers of QC immunoreactive 
Fig. 5 pE-A $\beta$ forms the core of $\mathrm{A} \beta$ deposits. $\mathrm{pE}-\mathrm{A} \beta$ (left, green) is localized in the center of $A \beta$ deposits in mouse hippocampus as shown by the double labelling with the antibody $4 \mathrm{G} 8$ (middle, red), which recognizes amino acids $17-24$ of $\mathrm{A} \beta$ peptides and, therefore, all $\mathrm{N}$ - and C-terminally truncated/ modified variants including $\mathrm{pE}$ $\mathrm{A} \beta$ as indicated by yellow colour in the overlay channel (right)

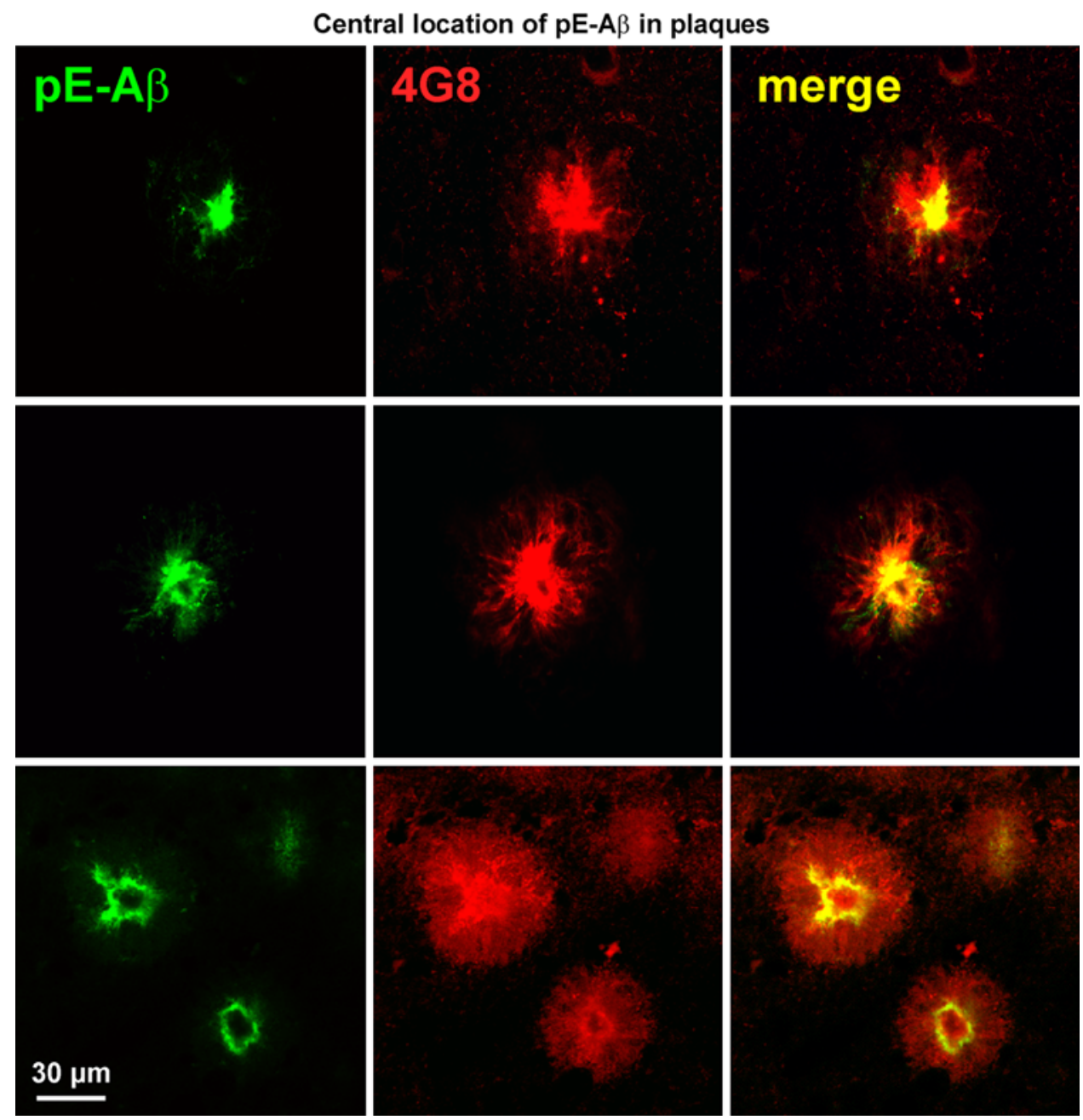

interneurons in mice, (3) it is affected by $\mathrm{pE}-\mathrm{A} \beta$ pathology and (4) it receives afferents from projection neurons of the entorhinal cortex and locus coeruleus, which were shown to robustly express QC in mouse and human brain [36]. Moreover, hippocampal neurons are involved in the realization of higher cognitive function such as spatial orientation, learning and memory formation as well as in the processing of emotion and stress (reviewed in [4, 19]) and are affected by both, tau and $A \beta$ pathology, at early stages of AD [8]. Thus, dysfunction or degeneration of hippocampal neurons has been shown to contribute to cognitive decline in AD patients [22, 46, 58]. Although the cellular and molecular mechanisms contributing to hippocampal pathology and neurodegeneration are not well established, there is recent solid evidence that the $\mathrm{pE}$-modification of $\mathrm{N}$-truncated $\mathrm{A} \beta$ peptides contributes to the formation of neurotoxic high molecular weight $\mathrm{A} \beta$ aggregates [1, 26, 42, 59]. This modification is catalyzed by $\mathrm{QC}$ at an acidic $\mathrm{pH}$ optimum present at intracellular sites of $\mathrm{A} \beta$ generation $[14,47]$. However, thorough histopathological evidence for a role of $\mathrm{QC}$ in $\mathrm{pE}-\mathrm{A} \beta$ generation has still been lacking and, therefore, was addressed in this study.

In the human hippocampal formation from $\mathrm{AD}$ patients we observed a strikingly laminated appearance of $\mathrm{pE}-\mathrm{A} \beta$ deposits in the DG molecular layer and a marked $\mathrm{pE}-\mathrm{A} \beta$ pathology in stratum lacunosum moleculare of CA1, CA2 and CA3 subfields as well as in the subiculum. We detected a similar pattern of $\mathrm{A} \beta$ deposition using antibodies against full-length $A \beta$ peptides in our brain material. This is consistent with the previously demonstrated layer-specific A $\beta$ deposition in $\mathrm{AD}$ hippocampus [7, 12]. Interestingly, two types of $\mathrm{pE}-\mathrm{A} \beta$ deposits were identified: cored/focal $\mathrm{pE}-\mathrm{A} \beta$ aggregates, frequently associated with QC-immunoreactive neurons or neuronal debris and more diffuse $\mathrm{pE}-\mathrm{A} \beta$ deposits not associated with QC neurons. Both types of plaques were found to be composed of $\mathrm{pE}-\mathrm{A} \beta$ and of their unmodified counterparts with $\mathrm{pE}-\mathrm{A} \beta$ being present in the center and full-length $A \beta$ in the periphery of the deposits. We did not observe $\mathrm{pE}-\mathrm{A} \beta$ immunonegative plaques. In the present study six out of seven control subjects were devoid of hippocampal $\mathrm{pE}-\mathrm{A} \beta$ plaque pathology. One non- 
demented control subject displayed moderate $\mathrm{pE}-\mathrm{A} \beta$ plaque immunoreactivity in the hippocampus.

In order to further assess the role of QC in the formation of distinct types of $\mathrm{pE}-\mathrm{A} \beta$ deposits, brains of APP transgenic mice were analysed. Similar to the pathology in the brains from $\mathrm{AD}$ patients, $\mathrm{pE}-\mathrm{A} \beta$ aggregates in brains of Tg2576 mice were first detected in the entorhinal cortex, around PM 10. This indicates that all prerequisites for $\mathrm{pE}-$ $\mathrm{A} \beta$ generation such as transgenic human APP expression, as well as $\beta$ - and $\gamma$-secretase activity, $\mathrm{N}$-terminal $\mathrm{A} \beta$ truncation and QC activity are present and active in entorhinal cortex neurons. The density of $\mathrm{pE}-\mathrm{A} \beta$ aggregates steadily increased in entorhinal cortex and additional neocortical structures were subsequently affected by $\mathrm{pE}$ $\mathrm{A} \beta$ pathology during the aging process of $\mathrm{Tg} 2576$ mice.

In the Tg2576 hippocampal formation, $\mathrm{pE}-\mathrm{A} \beta$ deposits were first detected around PM 14 in the DG molecular layer. Additionally, starting at PM 16, there was formation of $\mathrm{pE}-\mathrm{A} \beta$ aggregates at sites of $\mathrm{QC}$ immunoreactive somata in the stratum lacunosum moleculare of the hippocampus proper. In many cases, these latter $\mathrm{pE}-\mathrm{A} \beta$ aggregates displayed a neuron-like shape, were co-localized with QC and contained a cellular nucleus in the center. Thus, we conclude that $\mathrm{pE}-\mathrm{A} \beta$ peptides in the stratum lacunosum moleculare might be generated intracellularly and accumulate in the somata of local QC-expressing interneurons. At later stages these intracellular aggregates may eventually become detrimental to the cell leading to the nuclear and somatic "crater-like" disintegration of QC/pE-A $\beta$-coexpressing neurons in this hippocampal subregion. In contrast, $\mathrm{pE}-\mathrm{A} \beta$ deposits in the DG molecular layer, which only sparsely contains QC immunoreactive interneurons [25], frequently lacked this neuron-like shape, did not display a central nucleus and had a diffuse structure. These observations are consistent with those made in $\mathrm{AD}$ hippocampus raising the question about the role of $\mathrm{QC}$ and the cellular and molecular mechanisms contributing to diffuse $\mathrm{pE}-\mathrm{A} \beta$ deposition in the $\mathrm{DG}$ molecular layer.

Interestingly, this hippocampal layer receives afferent input from QC-rich entorhinal cortex neurons that are affected early by $\mathrm{pE}-\mathrm{A} \beta$ pathology, via the perforant and alvear pathways. In particular, layer II entorhinal cortex neurons innervate the DG molecular layer, and neurons of layer III project to the stratum lacunosum moleculare of cornu ammonis [57, 61], the very hippocampal layers along which $\mathrm{pE}-\mathrm{A} \beta$ plaques are formed most consistently. This structural connectivity opens the possibility of an additional independent plaque-inducing mechanism, namely hippocampal $\mathrm{pE}-\mathrm{A} \beta$ seeding via axonal transport processes and synaptic release from terminals of entorhinal cortex projection neurons. Indeed, axonal transport of APP and $A \beta$-containing fragments via the perforant path [10] and deposition of $A \beta$ in terminal zones of the entorhinal- dentate projection in APP transgenic mice [54] have already been described. Compelling evidence for a causative role of perforant path afferents in the development of hippocampal $\mathrm{A} \beta$ plaque pathology, however, derives from a number of lesion studies. Both, ablation of the entorhinal cortex as well as transection of the perforant path result in significantly decreased amyloid burden in the hippocampus of APP transgenic mice [28, 53]. Importantly, entorhinal cortex lesions in APP/PS1-transgenic mice solely lead to a marked reduction in the number of diffuse but not of focal $\mathrm{A} \beta$ deposits in the deafferented dentate gyrus [56] also suggesting different plaque-inducing mechanisms. Additionally, selective overexpression of human mutant APP in mouse entorhinal cortex layer II/III neurons resulted in behavioural abnormalities characteristic for widespread neuronal APP overexpression, and in deficits in hippocampus-dependent spatial learning and memory [24].

The occurrence of two distinct types of neuron-related $\mathrm{A} \beta$ deposits, diffuse and focal plaques, is also a wellknown feature of the human brain parenchyma affected by $\mathrm{AD}$ as reviewed by Duyckaerts et al. [17]. Here, we demonstrate an analogous pattern of the formation of diffuse and dense core $\mathrm{pE}-\mathrm{A} \beta$ containing plaques in mouse and human brain affected by $A \beta$ pathology. We conclude that $\mathrm{QC}$, the enzyme catalyzing the $\mathrm{pE}$-modification of $\mathrm{A} \beta$, may contribute to the formation of morphologically distinct types of $\mathrm{pE}-\mathrm{A} \beta$ plaques via different mechanisms. These include local $\mathrm{pE}-\mathrm{A} \beta$ generation at sites of $\mathrm{QC}$-expressing hippocampal interneurons and $\mathrm{QC}$ and/or $\mathrm{pE}-\mathrm{A} \beta$ transport from entorhinal cortex projection neurons and layer-specific synaptic release at hippocampal terminal zones. However, we would like to stress that diffuse $\mathrm{pE}-\mathrm{A} \beta$ aggregates detected in this study may not be exclusively present in the extracellular space, but could also be localized within neurites of QC-rich neurons arising from entorhinal cortex or hippocampal subfields.

A similar mechanism contributing to laminar hippocampal $\mathrm{pE}-\mathrm{A} \beta$ plaque pathology may apply to subcortical neuronal projections. Thorough anatomical investigations have demonstrated that the hippocampus receives widespread and layer-specific noradrenergic input from the locus coeruleus [5, 29]. This neuronal population has recently been shown to express high amounts of QC in mouse and human brain and to display significant $\mathrm{pE}-\mathrm{A} \beta$ pathology in $\mathrm{AD}$ [36]. Thus, diffuse $\mathrm{pE}-\mathrm{A} \beta$ plaques observed in the $\mathrm{Tg} 2576$ stratum lacunosum moleculare of the hippocampus proper may also result from secretion of pE-A $\beta$ generated by locus coeruleus neurons.

Alternatively, QC itself may be anterogradly transported and released in target regions of projection neurons, and then modify extracellularly deposited $\mathrm{N}$-truncated $\mathrm{A} \beta$ peptides. Indeed, there is solid cell physiological evidence to support this notion. For example, QC was found to be 

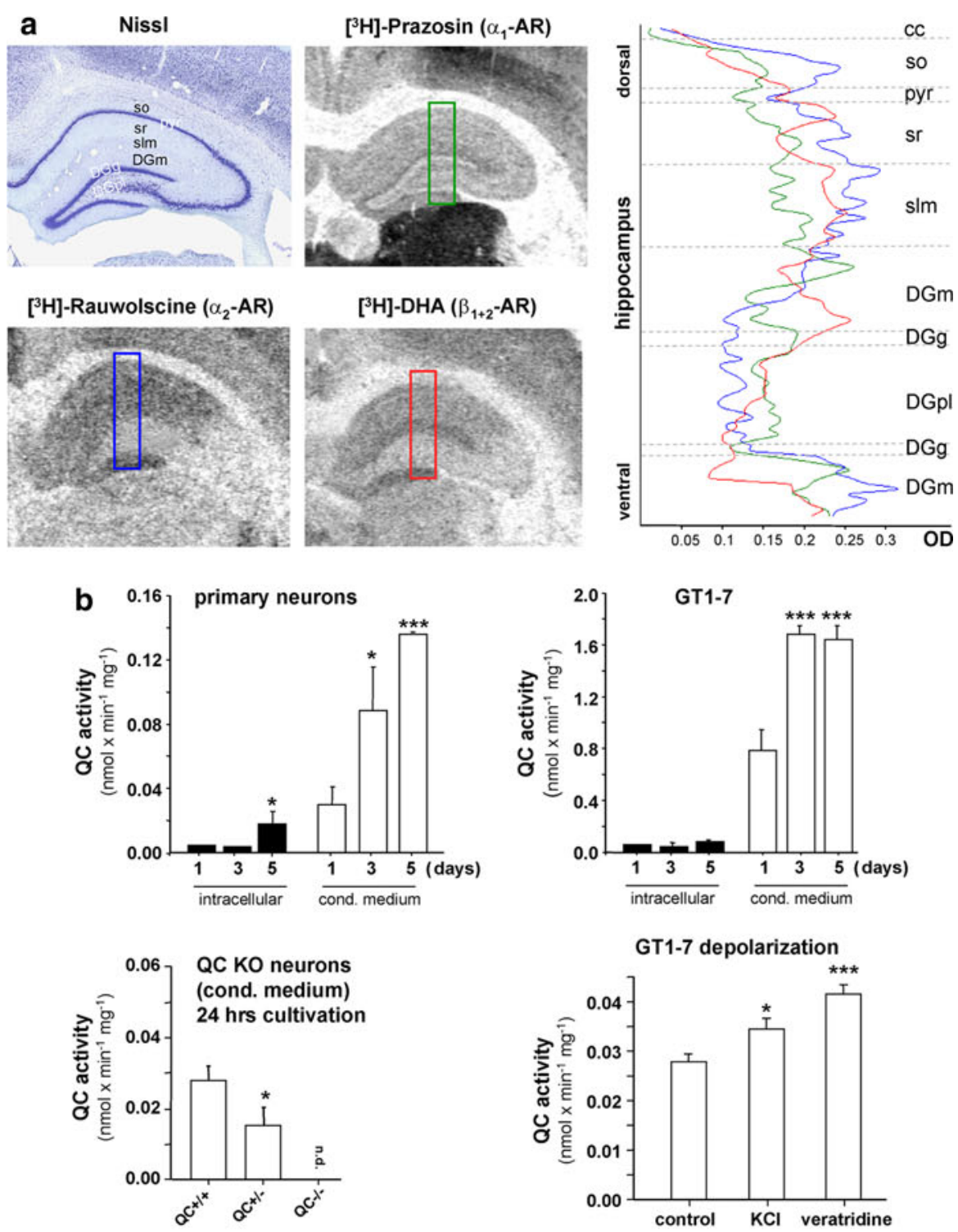

GT1-7 depolarization
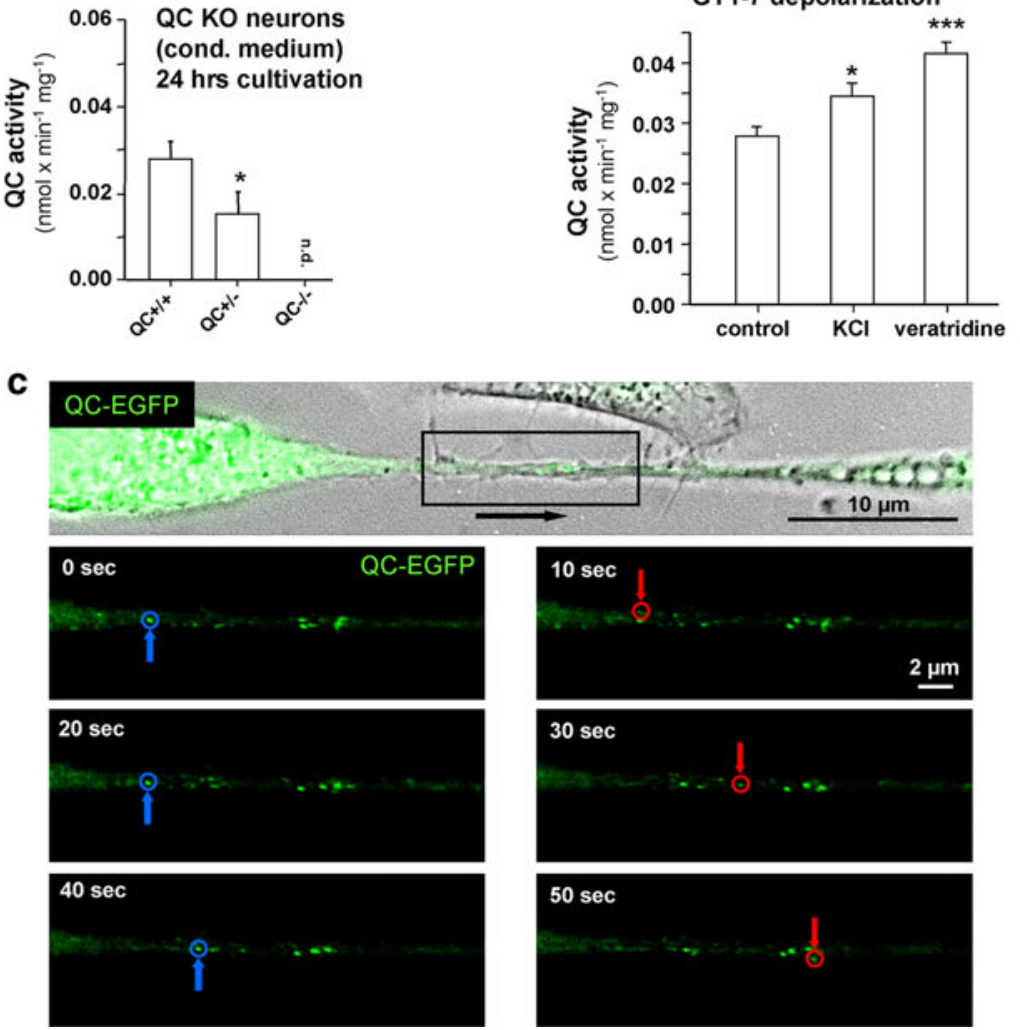
4 Fig. 6 Noradrenergic input to hippocampal layers and secretion of QC from cultured neurons. a The noradrenergic input to the hippocampal formation was visualized by the lamina-specific detection of $\alpha 1, \alpha 2$ and $\beta 1 / 2$ noradrenergic receptor subtypes using receptor autoradiography. Note the dense labelling for $\beta 1 / 2$ adrenoceptors in the DG molecular layer and for $\alpha 2$ adrenoceptors in the DG molecular layer and in the strata lacunosum moleculare and radiatum of cornu ammonis. b QC enzymatic activity in conditioned medium (open bars) of cultured mouse primary neurons (top left) and of hypothalamic GT1-7 cells (top right) is significantly higher than intraneuronal QC activity (black bars). Additionally, in both cell types intraneuronal QC activity was rather stable during a cultivation period of 5 days, whereas QC activity in the conditioned medium increased steadily, consistent with its constitutive secretion. Moreover, in the conditioned medium from QC knock-out mouse neurons cultured for $24 \mathrm{~h}$, the enzymatic QC activity was reduced in a gene dose-dependent manner (bottom left). Depolarization of GT1-7 cells by $50 \mathrm{mM} \mathrm{KCl}$ or $50 \mu \mathrm{M}$ veratridine treatment for 15 min resulted in a modest increase in QC secretion by 24 and 53\%, respectively (bottom right). Statistically significant by one-way ANOVA, followed by post-hoc analysis (Newman-Keuls test) at $* p<0.05$ and $* * * p<0.001$ compared to day 1 or respective control sample. c Live cell imaging of GT1-7 neurons expressing QC-EGFP. GT1-7 cells were differentiated by serum deprivation for $72 \mathrm{~h}$ and then transfected with QC-EGFP constructs. Twelve hours after transfection GT1-7 cells expressing the QC-EGFP fusion protein were identified by EGFP fluorescence (top). Three images per second were taken and representative examples are shown in 10-s intervals to demonstrate fast transport of QC-EGFP (botttom, red and blue circles)

localized along the secretory pathway; i.e. endoplasmic reticulum, trans-Golgi network and secretory granules in mouse brain neurons [25]. Moreover, the QC live imaging and enzymatic activity data presented here indicate a constitutive secretion of QC from neurons under basal physiological conditions. Thus, the high QC levels of entorhinal cortex and noradrenergic locus coeruleus neurons, their substantial projections to the DG molecular layer and stratum lacunosum moleculare of the hippocampus proper and the secretion of QC from cultured neurons are supportive for a role of secreted $\mathrm{pE}-\mathrm{A} \beta$ and/or $\mathrm{QC}$ in the generation of diffuse $\mathrm{pE}-\mathrm{A} \beta$ deposits. Such a "seeding from the distance" of $A \beta$ plaques by brainstem locus coeruleus neurons has already been discussed to contribute to the development of AD pathology [37]. Furthermore, in an APP transgenic mouse model, the seeding of $A \beta$ deposits in brain structures lacking transgene expression has been shown via synaptic $A \beta$ release from projection neurons [11]. These data are also consistent with an animal experimental study in which embryonic foetal cells were grafted into the brains of APP23 mice. The authors observed diffusion of soluble $A \beta$ in the extracellular space and concluded that this process is involved in the spread of $A \beta$ pathology and in neurodegeneration [33]. Also, the thorough analysis of brains from AD patients and from non-demented controls suggests defined phases of $A \beta$ formation and the expansion of the pathology from neocortical to allocortical brain regions, followed by diencephalic, brainstem and cerebellar $A \beta$ deposition [55].

Considering the sublayer-specific plaque formation in Tg2576 mouse hippocampus it has to be noted, however, that the DG polymorphic layer barely develops $\mathrm{pE}-\mathrm{A} \beta$ pathology. While the absence of diffuse $\mathrm{pE}-\mathrm{A} \beta$ deposits is consistent with the lack of entorhinal projection terminals and noradrenergic receptors, the absence of dense core $\mathrm{pE}$ $\mathrm{A} \beta$ plaque pathology in spite of the presence of $\mathrm{QC}$ expressing interneurons in this area was unexpected. However, $\mathrm{pE}-\mathrm{A} \beta$ formation in $\mathrm{Tg} 2576$ mice does not only require QC activity, but also human APP expression, its processing by $\beta$ - and $\gamma$-secretases and, finally, $\mathrm{N}$-terminal truncation to generate the QC substrate. Therefore, the absence of one or more factors indispensable for $\mathrm{pE}-\mathrm{A} \beta$ formation may explain this phenomenon.

Our observations on the central localization of $\mathrm{pE}-\mathrm{A} \beta$ peptides within $A \beta$ plaques match biochemical data suggesting that $\mathrm{pE}-\mathrm{A} \beta$ peptides act as seed for aggregation and co-aggregation of non-modified $A \beta$ peptides $[15,31,51]$. In all morphologically distinct types of $A \beta$ aggregates investigated here, $\mathrm{pE}-\mathrm{A} \beta$ was always detected in the core of the deposited material. Taken together, we describe two morphologically distinct types of $\mathrm{pE}-\mathrm{A} \beta$ aggregates in the hippocampus of AD patients and of Tg2576 mice, which can be spatially related to local QC-expressing interneurons and to target fields of QC-rich projection neurons arising in entorhinal cortex and/or locus coeruleus, respectively. These data provide histopathological evidence for $\mathrm{QC}$ being a prerequisite for $\mathrm{pE}-\mathrm{A} \beta$ pathology in vivo and further underline the therapeutic potential of QC inhibition in AD.

Acknowledgments We are grateful to the Banner Sun Health Research Institute Brain Donation Program of Sun City, Arizona, for the provision of human brain tissue. The Brain Donation Program is supported by the National Institute on Aging (P30 AG19610 Arizona Alzheimer's Disease Core Center), the Arizona Department of Health Services (contract 211002, Arizona Alzheimer's Research Center), the Arizona Biomedical Research Commission (contracts 4001, 0011, 05-901 and 1001 to the Arizona Parkinson's Disease Consortium) and the Michael J. Fox Foundation for Parkinson's Research. GT1-7 cells were a generous gift from I. Vorberg/H. Schätzl; Institute of Virology at Technical University of Munich. We thank R. Jendrek (Paul Flechsig Institute for Brain Research), K. Schulz and E. Scheel (Probiodrug) for technical assistance. This work was supported by the German Federal Department of Education, Science and Technology, BMBF [grant \#3013185 to H.U.D.] and by the 7th Framework Programm Health of the European Commission [Neuropro, Grant Agreement \#223077 to S.R.]. M.M. is member of the Graduiertenkolleg GRK 1097 funded by the German Research Foundation and of the $\mathrm{MD} / \mathrm{PhD}$ program at the Universität Leipzig.

Open Access This article is distributed under the terms of the Creative Commons Attribution Noncommercial License which permits any noncommercial use, distribution, and reproduction in any medium, provided the original author(s) and source are credited. 


\section{References}

1. Acero G, Manutcharian K, Vasilevko V et al (2009) Immunodominant epitope and properties of pyroglutamate-modified $\mathrm{A} \beta$ specific antibodies produced in rabbits. $J$ Neuroimmunol 213:39-46

2. Armstrong RA (1998) $\beta$-Amyloid plaques: stages in life history or independent origin? Dement Geriatr Cogn Disord 9:227-238

3. Beach TG, Sue LI, Walker DG et al (2008) The Sun Health Research Institute Brain Donation Program: description and experience, 1987-2007. Cell Tissue Bank 9:229-245

4. Bird CM, Burgess N (2008) The hippocampus and memory: insights from spatial processing. Nat Rev Neurosci 9:182-194

5. Blackstad TM, Fuxe K, Hökfelt T (1967) Noradrenaline nerve terminals in the hippocampal region of the rat and guinea pig. Z Zellforsch 78:463-473

6. Böckers TM, Kreutz MR, Pohl T (1995) Glutaminyl-cyclase expression in the bovine/porcine hypothalamus and pituitary. J Neuroendocrinol 7:445-453

7. Braak H, Braak E (1991) Alzheimer's disease affects limbic nuclei of the thalamus. Acta Neuropathol 81:261-268

8. Braak H, Braak E (1991) Neuropathological stageing of Alzheimer-related changes. Acta Neuropathol 81:239-259

9. Busby WH, Quackenbush GE, Humm J, Youngblood WW, Kizer JS (1987) An enzyme(s) that converts glutaminyl-peptides into pyroglutamyl-peptides. J Biol Chem 262:8532-8536

10. Buxbaum JD, Thinakaran G, Koliatsos V et al (1998) Alzheimer amyloid protein precursor in the rat hippocampus: transport and processing through the perforant path. J Neurosci 18:9629-9637

11. Christensen DZ, Kraus SL, Flohr A, Cotel MC, Wirths O, Bayer TA (2008) Transient intraneuronal A $\beta$ rather than extracellular plaque pathology correlates with neuron loss in the frontal cortex of APP/PS1 mice. Acta Neuropathol 116:647-655

12. Crain BC, Burger PC (1988) The laminar distribution of neuritic plaques in the fascia dentata of patients with Alzheimer's disease. Acta Neuropathol 76:87-93

13. Cynis H, Schilling S, Bodnar M et al (2006) Inhibition of glutaminyl cyclase alters pyroglutamate formation in mammalian cells. Biochim Biophys Acta 1764:1618-1625

14. Cynis H, Scheel E, Saido TC, Schilling S, Demuth HU (2008) Amyloidogenic processing of amyloid precursor protein: evidence of a pivotal role of glutaminyl cyclase in generation of pyroglutamate-modified amyloid-beta. Biochemistry 47:74057413

15. D'Arrigo C, Tabaton M, Perico A (2009) N-terminal truncated pyroglutamyl beta amyloid peptide Abetapy3-42 shows a faster aggregation kinetics than the full-length Abeta1-42. Biopolymers 91:861-873

16. Dickson TC, Vickers JC (2001) The morphological phenotype of $\beta$-amyloid plaques and associated neuritic changes in Alzheimer's disease. Neuroscience 105:99-107

17. Duyckaerts C, Delatour B, Potier MC (2009) Classification and basic pathology of Alzheimer disease. Acta Neuropathol 118:5-36

18. Duvernoy HM (2005) The human hippocampus. Functional anatomy, vascularization and serial sections with MRI, 3rd edn. Springer, Berlin

19. Fanselow MS, Dong HW (2010) Are the dorsal and ventral hippocampus functionally distinct structures? Neuron 65:7-19

20. Fischer WH, Spiess J (1987) Identification of a mammalian glutaminyl cyclase converting glutaminyl into pyroglutamyl peptides. Proc Natl Acad Sci USA 84:3628-3632

21. Förster E, Zhao S, Frotscher M (2006) Laminating the hippocampus. Nat Rev Neurosci 7:259-267
22. Fukutani Y, Cairns NJ, Shiozawa M et al (2000) Neuronal loss and neurofibrillary degeneration in the hippocampal cortex in late-onset sporadic Alzheimer's disease. Psychiatry Clin Neurosci 54:523-529

23. Haass C (2004) Take five-BACE and the gamma-secretase quartet conduct Alzheimer's amyloid beta-peptide generation. EMBO J 23:483-488

24. Harris JA, Devidze N, Verret L et al (2010) Transsynaptic progression of amyloid-b-induced neuronal dysfunction within the entorhinal-hippocampal network. Neuron 68:428-441

25. Hartlage-Rübsamen M, Staffa K, Waniek A et al (2009) Developmental expression and subcellular localization of glutaminyl cyclase in mouse brain. Int J Dev Neurosci 27:825-835

26. He W, Barrow CJ (1999) The A beta 3-pyroglutamyl and 11-pyroglutamyl peptides found in senile plaque have greater beta-sheet forming and aggregation propensities in vitro than fulllength A beta. Biochemistry 38:10871-10877

27. Heider M, Schliebs R, Roßner S, Bigl V (1997) Basal forebrain cholinergic immunolesion by 192IgG-saporin: evidence for a presynaptic location of subpopulations of alpha 2- and betaadrenergic as well as 5-HT2A receptors on cortical cholinergic terminals. Neurochem Res 22:957-966

28. Lazarov O, Lee M, Peterson DA, Sisodia SS (2002) Evidence that synaptically released beta-amyloid accumulates as extracellular deposits in the hippocampus of transgenic mice. J Neurosci 22:9785-9793

29. Loy R, Koziell DA, Lindsey JD, Moore RY (1980) Noradrenergic innervation of the adult rat hippocampal formation. J Comp Neurol 189:699-710

30. Mai JK, Assheuer J, Paxinos G (2004) Atlas of the human brain. Academic Press, San Diego

31. McColl G, Roberts BR, Gunn AP et al (2009) The Caenorhabditis elegans A $\beta 1-42$ model of Alzheimer's disease predominantly expresses A $33-42$. J Biol Chem 284:22697-22702

32. Mellon PL, Windle JJ, Goldsmith PC, Padula CA, Roberts JL, Weiner RI (1990) Immortalization of hypothalamic GnRH neurons by genetically targeted tumorigenesis. Neuron 5:1-10

33. Meyer-Luehmann M, Stalder M, Herzig MC et al (2003) Extracellular amyloid formation and associated pathology in neural grafts. Nat Neurosci 6:370-377

34. Miravalle L, Calero M, Takao M, Roher AE, Ghetti B, Vidal R (2005) Amino-terminally truncated Abeta peptide species are the main component of cotton wool plaques. Biochemistry 44:10810-10821

35. Mirra SS, Heyman A, McKeel D et al (1991) The Consortium to Establish a Registry for Alzheimer's Disease (CERAD). Part II. Standardization of the neuropathologic assessment of Alzheimer's disease. Neurology 41:479-486

36. Morawski M, Hartlage-Rübsamen M, Jäger C et al (2010) Distinct glutaminyl cyclase expression in Edinger-Westphal nucleus, locus coeruleus and nucleus basalis Meynert contributes to pGluA $\beta$ pathology in Alzheimer's disease. Acta Neuropathol 120:195-207

37. Muresan Z, Muresan V (2008) Seeding neuritic plaques from the distance: a possible role for brainstem neurons in the development of Alzheimer's disease. Neurodegener Dis 5:250-253

38. Piccini A, Russo C, Gliozzi A et al (2005) Beta-amyloid is different in normal aging and in Alzheimer's disease. J Biol Chem 280:34186-34192

39. Pohl T, Zimmer M, Mugele K, Spiess J (1991) Primary structure and functional expression of a glutaminyl cyclase. Proc Natl Acad Sci USA 88:10059-10063

40. Portelius E, Bogdanovic N, Gustavsson MK et al (2010) Mass spectrometric characterization of brain amyloid beta isoform signatures in familial and sporadic Alzheimer's disease. Acta Neuropathol 120:185-193 
41. Russo C, Schettini G, Saido TC et al (2000) Presenilin-1 mutations in Alzheimer's disease. Nature 405:531-532

42. Russo C, Violani E, Salis S et al (2002) Pyroglutamate-modified amyloid beta-peptides-AbetaN3(pE) — strongly affect cultured neuron and astrocyte survival. J Neurochem 82:1480-1489

43. Saido TC (1998) Alzheimer's disease as proteolytic disorders: anabolism and catabolism of beta-amyloid. Neurobiol Aging 19:S69-S75

44. Saido TC, Iwatsubo T, Mann DM, Shimada H, Ihara Y, Kawashima S (1995) Dominant and differential deposition of distinct beta-amyloid peptide species, Abeta N3(pE), in senile plaques. Neuron 14:457-466

45. Saido TC, Yamao H, Iwatsubo T, Kawashima S (1996) Aminoand carboxyl-terminal heterogeneity of beta-amyloid peptides deposited in human brain. Neurosci Lett 215:173-176

46. Scheff SW, Price DA, Schmitt FA, Mufson EJ (2006) Hippocampal synaptic loss in early Alzheimer's disease and mild cognitive impairment. Neurobiol Aging 27:1372-1384

47. Schilling S, Hoffmann T, Manhart S, Hoffmann M, Demuth HU (2004) Glutaminyl cyclases unfold glutamyl cyclase activity under mild acid conditions. FEBS Lett 563:191-196

48. Schilling S, Lauber T, Schaupp M et al (2006) On the seeding and oligomerization of pGlu-amyloid peptides (in vitro). Biochemistry 45:12393-12399

49. Schilling S, Zeitschel U, Hoffmann T et al (2008) Glutaminyl cyclase inhibition attenuates pyroglutamate Abeta and Alzheimer's disease-like pathology. Nat Med 14:1106-1111

50. Schilling S, Appl T, Hoffmann T et al (2008) Inhibition of glutaminyl cyclase prevents pGlu-A $\beta$ formation after intracortical/ hippocampal microinjection in vivo/in situ. $\mathrm{J}$ Neurochem 106:1225-1236

51. Schlenzig D, Manhart S, Cinar Y et al (2009) Pyroglutamate formation influences solubility and amyloidogenicity of amyloid peptides. Biochemistry 48:7072-7078
52. Selkoe DJ, Schenk D (2003) Alzheimer's disease: molecular understanding predicts amyloid based therapeutics. Annu Rev Pharmacol Toxicol 43:545-584

53. Sheng JG, Price DL, Koliatsos VE (2002) Disruption of corticocortical connections ameliorates amyloid burden in terminal fields in a transgenic model of $\mathrm{A} \beta$ amyloidosis. J Neurosci 22:9794-9799

54. Su Y, Ni B (1998) Selective deposition of amyloid-beta protein in the entorhinal-dentate projection of a transgenic mouse model of Alzheimer's disease. J Neurosci Res 53:177-186

55. Thal DR, Rüb U, Orantes M, Braak H (2002) Phases of A betadeposition in the human brain and its relevance for the development of AD. Neurology 58:1791-1800

56. van Groen T, Liu L, Ikonen S, Kadish I (2003) Diffuse amyloid deposition, but not plaque number, is reduced in amyloid precursor protein/presenilin 1 double-transgenic mice by pathway lesions. Neuroscience 119:1185-1197

57. van Groen T, Miettinen P, Kadish I (2003) The entorhinal cortex of the mouse: organization of the projection to the hippocampal formation. Hippocampus 13:133-149

58. von Gunten A, Kövari E, Bussière $T$ et al (2006) Cognitive impact of neuronal pathology in the entorhinal cortex and CA1 field in Alzheimer's disease. Neurobiol Aging 27:270-277

59. Wirths O, Breyhan H, Cynis H, Schilling S, Demuth HU, Bayer TA (2009) Intraneuronal pyroglutamate-Abeta 3-42 triggers neurodegeneration and lethal neurological deficits in a transgenic mouse model. Acta Neuropathol 118:487-496

60. Wirths O, Bethge T, Marcello A et al (2010) Pyroglutamate Abeta pathology in APP/PS1KI mice, sporadic and familial Alzheimer's disease cases. J Neural Transm 117:85-96

61. Witter MP (2007) The perforant path: projections from the entorhinal cortex to the dentate gyrus. Prog Brain Res 163:43-61 